\title{
Energy Analysis and Greenhouse Gas Emission from Strawberry Production under Two Irrigation Systems
}

\author{
Hossein KAZEMI* and Sanaz ZARDARI
}

Department of Agronomy, Faculty of Plant Production, Gorgan University of Agricultural Sciences and Natural Resources, Gorgan, Iran

('Corresponding author's e-mail: hkazemi@gau.ac.ir)

Received: 28 April 2016, Revised: 16 September 2018, Accepted: 18 October 2018

\begin{abstract}
The aims of this study were to estimate the energy indices, greenhouse gas (GHG) emission and compare the energy balance of open field strawberry production under furrow and drip irrigation systems in Kurdistan province, west of Iran. Data used in this study were obtained from 24 strawberry growers using a face to face questionnaire method in 2014. In order to convert inputs and output into energy equivalents, energy equivalent coefficients were applied. The results indicate that total energy consumption in strawberry production was 16,206.83 and 16,525.69 MJ.ha ${ }^{-1}$, whereas the total energy output was 38,950.00 and 52,385.70 $\mathrm{MJ}^{-h^{-1}}$ in furrow and drip irrigation systems, respectively. Energy use efficiency and net energy in the drip irrigation system were higher than the furrow irrigation system. Nitrogen fertilizer was the major energy consumer in both of the irrigation systems. From an environmental viewpoint, the total GHG emissions were 764.28 and $1,284.19 \mathrm{~kg} \mathrm{CO}_{2}$ equivalent ha ${ }^{-1}$ in the furrow and drip systems, respectively. In the furrow system, the nitrogen fertilizer and diesel fuel had the highest share in GHG emissions, with 51.76 and 20.72 percent of the total, respectively, but in the drip system, machinery had the highest share in GHG emissions, with 53.11 percent of the total.
\end{abstract}

Keywords: Energy use efficiency, net energy, strawberry production, GHG emissions

\section{Introduction}

Agriculture production is the process of converting the energy of solar radiation into metabolisable forms of energy and nutrients through photosynthetic pathways, aided by external inputs in the form of seeds, tillage, water, nutrients, weed control, and other practices aimed at improving the growing conditions for the crops [1]. Energy use in the agricultural sector has become more intensive due to the use of fossil fuels, chemical fertilizers, pesticides, machinery and electricity to provide substantial increases in food production. However, more intensive energy use has brought some important human health and environment problems so efficient use of inputs has become important in terms of sustainable agricultural production [2].

Increasing the use of energy inputs in cropping systems led to numerous environmental problems like GHG emissions, loss of biodiversity, high consumption of non-renewable energy resources and pollution of the environment $[3,4]$. There are both financial and environmental reasons to improve energy use efficiency in agricultural systems. From an environmental viewpoint, energy use in agriculture is associated with carbon dioxide $\left(\mathrm{CO}_{2}\right)$ emissions which has serious implications for climate change. From a financial viewpoint, energy generally costs money [5].

Nowadays, global warming is one of the most important issues. Burning fossil fuels results in the emission of $\mathrm{CO}_{2}$, nitrous oxide $\left(\mathrm{N}_{2} \mathrm{O}\right)$ and methane $\left(\mathrm{CH}_{4}\right)$ that act as barriers to thermal radiation and prevent it from leaving the earth's atmosphere [6]. Agricultural GHG emissions account for $10-12 \%$ of all anthropogenic GHG emissions. So, use of different forms of energy and its negative effects are 
http://wjst.wu.ac.th

indivisible [4]. A reduction in GHG emissions by minimising the amount of fossil fuels burnt is therefore vital to reduce global warming [7].

Current farming systems have become very energy intensive. There is a great need to balance the use and availability of energy, particularly in the agricultural sector [8]. The energy balance approach for determination of agronomic efficiency requires quantification of the total energy of external inputs expended on crop production and the energy yield in the form of human appropriated yield [1]. Total input of energy in cropping systems increases with an increase in management intensity. Therefore, selection of an appropriate method includes evaluation of the system's efficiency control [9]. In India, a study was conducted to assess the EUE and GHG emissions of different tillage practices in pigeon peacastor systems under semi-arid rainfed regions. Results showed that the use of fossil fuels in zero tillage was 58 and $81 \%$ lower than conventional tillage in pigeonpea and castor cropping systems, respectively [10]. In Iran, Banaeian et al. reported that greenhouse strawberry production consumed in total

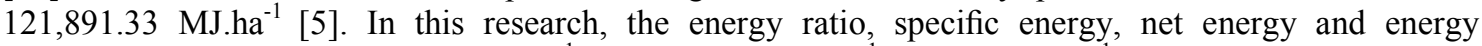
intensiveness were $0.15,12.55 \mathrm{MJ} . \mathrm{kg}^{-1}, 683,488.37 \mathrm{MJ} . \mathrm{ha}^{-1}$ and $8.18 \mathrm{MJ} . \$^{-1}$, respectively. In another paper, Royan et al. studied the energy balance between the energy inputs and yield in peach production in Golestan province, northeastern Iran as a case study. The results showed that total energy consumption in peach production was 37,536.96 MJ.ha ${ }^{-1}$ where the diesel fuel with about $26.32 \%$ was the major energy consumer [11]. Ren et al. investigated the energy productivity and input sensitivity of sweet sorghum as compared with cotton and maize, at 2 coastal saline-alkali sites in Shandong province, China. The energy balance analysis showed that sweet sorghum had a lower energy input requirement than maize and cotton in these sites. The results of this study revealed that the diesel fuel and nitrogen fertilizer energy inputs had a significantly positive impact on the sweet sorghum energy output [12].

Surface, sprinkler, and gravity drip irrigations are 3 common systems in Iran. Surface irrigation is the oldest and most common system in this country. It does not require special technology and equipment. Surface irrigation is applied as basin, border or furrow irrigations. Drip irrigation has proved very satisfactory in irrigating plants in sandy soils where it is not feasible to apply common surface or sprinkler irrigation systems. In this irrigation method, the plant receives chemical fertilizers directly, and then the fertilizer and water use efficiency are increased. Drip irrigation systems produce excellent results with crops such as grapes, peanuts, pistachios, apples and watermelons [13]. Strawberries are produced both on open field and under cover in greenhouses in Iran. It is mostly cultivated on open fields with a furrow irrigation system in Kurdistan province, west of Iran. In this province, open field strawberry production as a conventional method has been used to supply the domestic demand for this crop. The total land area cultivated for strawberries was 2,553 ha in Kurdistan province and this amount was 1,610 ha in Sanandaj township in 2013. In this year, the total strawberry production was 33,243 tones in this province, about 63 $\%$ of total strawberry production obtained from Sanandaj township [14].

The energy analysis shows the methods to minimize the energy inputs and therefore to increase the energy productivity [15]. Several studies have evaluated the energy balance in different crops' production [16-21] but very few studies have combined the energy analysis and GHG emissions for strawberry production under different irrigation systems. Therefore, the aims of this research were to undertake energy analysis and determine GHG emission from strawberry production under furrow and drip systems in Kurdistan province.

\section{Materials and methods}

\section{Description of the site and agricultural practices}

The study was carried out in Kurdistan province within $34^{\circ} 44^{\prime}-36^{\circ} 30^{\prime}$ north latitude and $45^{\circ} 31^{\prime}$ - $48^{\circ} 16^{\prime}$ east longitude. Kurdistan is one of the most mountainous regions in Iran and the total area of this province is $2,820,300$ ha. It is located in the west of Iran, and bound by Iraq on the west, the province of West Azerbaijan to its north, Zanjan to the northeast, Hamedan to the east and Kermanshah to the south. Sanandaj township is the capital of Kurdistan province. Other townships with their major cities are Marivan, Saqqez, Bijar, Baneh, Sarvabad, Diwandarreh, Kamyaran, Qorveh and Dehgolan. In these 
http://wjst.wu.ac.th

regions, wheat, barley, strawberries, food legumes and fruits are the main agricultural products. The average annual rainfall of this province is $450 \mathrm{~mm}$.

According to results of surveyed fields, the average farm size was 0.587 ha ranged from 0.2 to 1 ha. Land preparation and soil tillage, were generally done by a Massey Ferguson tractor using a moldboard plow and disc harrows. In the strawberry fields, land is tilled once and is disked 2 times. In this region, strawberries are mostly irrigated by furrow irrigation. Plant protection starts with application of pesticide and herbicide. Chemical fertilizers are applied approximately $1-2$ times. On average, the strawberry crop is hoed $1-2$ times by hand during the period of growth and harvested by hand during May-June.

\section{Data collection}

Data were collected from open field strawberry farmers in Kurdistan province using a face to face questionnaire performed in August-September 2014. Sample farms were randomly selected from the villages in the study area by using a random sampling technique. The equation is as below [17].

$\mathrm{n}=\left(\sum \mathrm{N}_{\mathrm{h}} \mathrm{S}_{\mathrm{h}}\right) /\left(\mathrm{N}^{2} \mathrm{D}^{2}+\sum \mathrm{N}_{\mathrm{h}} \mathrm{S}_{\mathrm{h}}^{2}\right)$

where $\mathrm{n}$ is the required sample size; $\mathrm{n}$ is the number of total holdings in the population; $\mathrm{N}_{\mathrm{h}}$ is the number of the population in $\mathrm{h} ; \mathrm{S}_{\mathrm{h}}^{2}$ is the variance of $\mathrm{h}$ stratification; $\mathrm{D}^{2}=\mathrm{d}^{2} / \mathrm{z}^{2} ; \mathrm{d}$ is the precision where $\left(\bar{x} \_\bar{X}\right)$; and, $\mathrm{z}$ is the reliability coefficient.

The permissible error in the sample size was defined to be $5 \%$ for $95 \%$ confidence and the sample size was calculated as 24 farms. Human labor, machinery, diesel fuel, chemical fertilizers, and chemicals and output yield values of crop have been used to investigate the energy flow. The quantity of inputs is demonstrated in Table 1. The energy used in applying each machine was calculated from the total weight and the economic life of the machine and the time needed to complete that operation [22]. Basic information on energy inputs and strawberry yields were entered into Excel spreadsheets.

Table 1 Energy equivalent of inputs and output in strawberry production.

\begin{tabular}{lccc}
\hline A. Inputs & Unit & $\begin{array}{c}\text { Energy equivalent } \\
\text { (MJ.unit } \mathbf{- 1}^{\mathbf{}}\end{array}$ & Reference \\
\hline Human labor & $\mathrm{h}$ & 1.96 & {$[2,8]$} \\
Machinery & $\mathrm{h}$ & 64.70 & {$[21]$} \\
Diesel fuel & $\mathrm{L}$ & 56.31 & {$[34]$} \\
Fertilizers & & & \\
Nitrogen $(\mathrm{N})$ & $\mathrm{kg}$ & 66.14 & {$[5]$} \\
Phosphate $\left(\mathrm{P}_{2} \mathrm{O}_{5}\right)$ & $\mathrm{kg}$ & 12.44 & {$[5]$} \\
Potassium $\left(\mathrm{K}_{2} \mathrm{O}\right)$ & $\mathrm{kg}$ & 11.15 & {$[5]$} \\
Micro-elements & $\mathrm{kg}$ & 120.00 & {$[26]$} \\
Chemicals & $\mathrm{kg}$ & 120.00 & {$[26]$} \\
Water for irrigation & $\mathrm{m}$ & 1.02 & {$[36]$} \\
B. Output & & & {$[5]$} \\
Strawberry & $\mathrm{kg}$ & 1.9 & \\
\hline
\end{tabular}

\section{Energy analysis}

Energy equivalents of inputs and outputs (Table 1) were exercised to assess the total energy inputs and outputs. Diesel fuel, machinery, fertilizers, chemicals, water for irrigation, human labor and output yield values of strawberry have been used to estimate the energy ratio. Different sources of energy have different energy values. Since the inputs were measured in different units, it was necessary to convert 
http://wjst.wu.ac.th

them into a common energy unit by using various energy coefficients. Energy coefficients for various sources of energy may thus be defined as energy equivalence of such sources of energy, taking into account all forms of energy inputs to their production. Table 1 gives energy values of different sources of energy. These coefficients have been recognized and accepted by various scientific communities as indicated in the last column.

The amounts of input were calculated per hectare and then, these input data were multiplied with the coefficient of energy equivalent. The total input equivalent can be calculated by adding up the energy components of all inputs in MJ. In this order the energy equivalents of the inputs and output, the energy use efficiency, energy productivity, net energy and the specific energy were calculated [17,21];

$$
\begin{aligned}
& \text { Energy use efficiency } \left.=\left[{\text { Energy output }\left(\text { MJ.ha }^{-1}\right) / \text { Energy input }(\text { MJ.ha }}^{-1}\right)\right] \\
& \text { Energy productivity }=\left[\text { Production }\left(\mathrm{kg} \cdot \mathrm{ha}^{-1}\right) / \text { Energy Input }\left(\mathrm{MJ} \cdot \mathrm{ha}^{-1}\right)\right] \\
& \text { Specific energy }=\left[\text { Energy Input }\left(\mathrm{MJ}^{\mathrm{h}} \mathrm{ha}^{-1}\right) / \text { Production }\left(\mathrm{kg} \cdot \mathrm{ha}^{-1}\right)\right] \\
& \text { Net energy }=\text { Energy Output }\left(\mathrm{MJ} \cdot \mathrm{ha}^{-1}\right)-\text { Energy Input }\left(\mathrm{MJ} \cdot \mathrm{ha}^{-1}\right)
\end{aligned}
$$

The input energy was divided into renewable and non-renewable and direct and indirect forms. Non-renewable energy includes diesel fuel, chemicals, chemical fertilizers, and machinery and renewable energy consists of human labor and water. Direct energy is directly used on fields. Indirect energy included energy embodied in seed, chemical, machinery and fertilizers while direct energy covered diesel fuel, human, water for irrigation and human labor used in the production process $[18,19]$.

\section{GHG emission analysis}

The amounts of GHG emissions from energy inputs in strawberry production per hectare were calculated by using $\mathrm{CO}_{2}$ emissions coefficient of agricultural inputs (Table 2). The amount of produced $\mathrm{CO}_{2}$ was calculated by multiplying the input application rate (chemical fertilizers, diesel fuel, machinery and fungicide) by its corresponding emission coefficient that is given in Table 2. Ultimately, GHG emissions were calculated and reported per hectare [4].

\section{Results and discussions}

\section{Energy analysis}

The results revealed that $1,276.80$ and $1,112.83 \mathrm{~h}$ of human labor and 8.50 and $38.21 \mathrm{~h}$ of machine power are required per hectare for strawberry production in furrow and drip systems, respectively (Table 3 and 4). The majority of human labor in the strawberry farms was used in the harvest, weeding, and planting operations. In Kurdistan province, the sources of human labor in strawberry farms are either family members or seasonal laborers. Introducing new machines reduced human labor in the industry, but in field activities human labor still plays a key role. Even now, human power is the main source $(73 \%)$ of energy in agricultural operations in many developing countries [23].

Total machinery power consumed for land preparation consisted of plowing, disking, land leveling and transportation. The amount of input energies from different sources and output energy are presented in Tables 3 and 4. These results showed that the total energy input in the drip system was $16,525.69 \mathrm{MJ}$ $\mathrm{ha}^{-1}$, and it was higher than the furrow system $\left(16,206.83 \mathrm{MJ} \mathrm{ha}^{-1}\right)$. The lower energy consumption in the furrow system was due to lower inputs of diesel fuel and machinery (Table 3). 
http://wjst.wu.ac.th

Table 2 GHG emission coefficients of agricultural inputs [4].

\begin{tabular}{lll}
\hline Input & Unit & GHG coefficient $\left(\mathbf{k g ~ C O}_{\mathbf{2 e q}}\right.$ unit $\left.^{-\mathbf{1}}\right)$ \\
\hline 1. Diesel fuel & $\mathrm{L}$ & 2.76 \\
2. Nitrogen fertilizer $(\mathrm{N})$ & $\mathrm{kg}$ & 1.3 \\
3. Phosphorous fertilizer $\left(\mathrm{P}_{2} \mathrm{O}_{5}\right)$ & $\mathrm{kg}$ & 0.2 \\
4. Potash fertilizer $\left(\mathrm{K}_{2} \mathrm{O}\right)$ & $\mathrm{kg}$ & 0.2 \\
5. Fungicide & $\mathrm{kg}$ & 6.3 \\
6. Machinery & $\mathrm{h}$ & 71 \\
\hline
\end{tabular}

Table 3 Amounts of inputs, output and energy inputs and output for strawberry production with furrow irrigation system in Kurdistan province, Iran.

\begin{tabular}{|c|c|c|c|c|}
\hline Inputs and output & Unit & $\begin{array}{l}\text { Quantity per unit } \\
\text { area (ha)(min-max) }\end{array}$ & $\begin{array}{c}\text { Total energy } \\
\text { equivalent }\left(\mathrm{MJ.ha}^{-1}\right)\end{array}$ & Percentage \\
\hline \multicolumn{5}{|l|}{ A. Inputs } \\
\hline 1. Human labor & $\mathrm{h}$ & $1,276.80(672-2,688)$ & $2,502.53$ & 15.44 \\
\hline 2. Machinery & $\mathrm{h}$ & $8.50(7-10)$ & 532.95 & 3.29 \\
\hline 3. Diesel fuel & 1 & $53.33(30-80)$ & $3,003.01$ & 18.53 \\
\hline 4. Chemical fertilizers & $\mathrm{kg}$ & & & \\
\hline a. Nitrogen & & $89.70(82.8-93)$ & $5,932.76$ & 36.61 \\
\hline b. Phosphate $\left(\mathrm{P}_{2} \mathrm{O}_{5}\right)$ & & $31.20(24-48)$ & 388.13 & 2.39 \\
\hline c. Potassium $\left(\mathrm{K}_{2} \mathrm{O}\right)$ & & $23.00(20-27)$ & 256.45 & 1.58 \\
\hline d. Micro elements & & $8.00(5-10)$ & 960.00 & 5.92 \\
\hline 5. Chemicals & $\mathrm{kg}$ & $4.50(3-6)$ & 540.00 & 3.33 \\
\hline 6. Water for irrigation & $\mathrm{m}^{3}$ & $2,050(900-3,400)$ & $2,091.00$ & 12.90 \\
\hline The total energy input & MJ & - & $16,206.83$ & 100 \\
\hline \multicolumn{5}{|l|}{ B. Output } \\
\hline 1. Strawberry fruit & $\mathrm{kg}$ & $20,500(17,000-25,000)$ & $3,8950.00$ & \\
\hline The total energy output & MJ & - & $3,8950.00$ & 100 \\
\hline
\end{tabular}

The contribution of different input energies used in strawberry production is illustrated in Tables 2 and 3. The results showed that nitrogen fertilizer with 36.61 and $30.25 \%$ has the highest share of total energy input from furrow and drip systems, respectively. Also, according to the data collected from all surveyed fields, energy input of nitrogen fertilizer has the highest share within all the chemical fertilizers. It indicates that average fertilizer use in the furrow and drip systems is 89.70 and $75.57 \mathrm{~kg}$.ha ${ }^{-1}$ for nitrogen and 31.20 and $30.90 \mathrm{~kg} \cdot$ ha $^{-1}$ for $\mathrm{P}_{2} \mathrm{O}_{5}$, respectively. It has been reported that energy input of nitrogen fertilizer has the biggest share of the total energy inputs in crops production [16-21]. However, in the Kurdistan region, the highest energy use belonged to diesel fuel, followed by nitrogen fertilizer which accounted about 18.53 and $24.70 \%$ of total energy consumption in furrow and drip systems (Tables 3 and 4). One of the main reasons for high consumption of diesel fuel is a temporal depreciation of machinery particularly in the pumps and tractors. In general, reduction of chemical fertilizers and fuel consumption are the most important ways of better energy management in strawberry production in the studied region. Based on the results, we recommend that the consumption of nitrogen fertilizers and diesel fuel are limited so that they can be effectively replaced by appropriate management practices. Djevic and 
http://wjst.wu.ac.th

Dimitrijevic determined that $92 \%$ of total energy in greenhouse lettuce production is diesel energy in Yugoslavia [24].

Table 4 Amounts of inputs, output and energy inputs and output for strawberry production with drip irrigation system in Kurdistan province, Iran.

\begin{tabular}{|c|c|c|c|c|}
\hline Inputs and output & Unit & $\begin{array}{l}\text { Quantity per unit } \\
\text { area (ha)(min-max) }\end{array}$ & $\begin{array}{c}\text { Total energy } \\
\text { equivalent }\left(\text { MJ.ha }^{-1}\right)\end{array}$ & Percentage \\
\hline \multicolumn{5}{|l|}{ A. Inputs } \\
\hline 1. Human labor & $\mathrm{h}$ & $\begin{array}{l}1,112.83(537.59- \\
1,612.79)\end{array}$ & $2,181.15$ & 13.20 \\
\hline 2. Machinery & $\mathrm{h}$ & $38.21(8-80)$ & $2,395.77$ & 14.50 \\
\hline 3. Diesel fuel & 1 & $72.50(30-100)$ & $4,082.48$ & 24.70 \\
\hline 4. Chemical fertilizers & $\mathrm{kg}$ & & & \\
\hline a. Nitrogen & & $75.57(46-138)$ & $4,998.20$ & 30.25 \\
\hline b. Phosphate $\left(\mathrm{P}_{2} \mathrm{O}_{5}\right)$ & & $30.90(19-48)$ & 384.40 & 2.33 \\
\hline c. Potassium $\left(\mathrm{K}_{2} \mathrm{O}\right)$ & & $20.00(17-22)$ & 223.00 & 1.35 \\
\hline d. Micro elements & & $5.00(5-5)$ & 600 & 3.63 \\
\hline 5. Chemicals & $\mathrm{kg}$ & $3.70(2-5)$ & 444.00 & 2.69 \\
\hline 6. Water for irrigation & $\mathrm{m}^{3}$ & $1,192.85(500-1,650)$ & $1,216.71$ & 7.36 \\
\hline The total energy input & MJ & - & $16,525.69$ & 100 \\
\hline \multicolumn{5}{|l|}{ B. Output } \\
\hline 1. Strawberry fruit & $\mathrm{kg}$ & $\begin{array}{l}27,571.42(18,000- \\
50,000)\end{array}$ & $52,385.70$ & \\
\hline The total energy output & MJ & - & $52,385.70$ & 100 \\
\hline
\end{tabular}

Table 5 The energy indices of strawberry production under 2 irrigation systems in Kurdistan province, Iran.

\begin{tabular}{lcll}
\hline \multirow{2}{*}{ Items } & \multirow{2}{*}{ Unit } & \multicolumn{2}{c}{ Quantity } \\
\cline { 3 - 4 } & & Furrow system & Drip system \\
\hline Energy use efficiency & - & 2.40 & 3.17 \\
Energy productivity & kg.MJ ${ }^{1}$ & 1.26 & 1.67 \\
Specific energy & MJ.kg- $^{-1}$ & 0.79 & 0.60 \\
Net energy & MJ.ha $^{-1}$ & $22,743.17$ & $35,860.01$ \\
\hline
\end{tabular}

The energy of the irrigated water $\left(2,091.00\right.$ and 1,216.71 MJ.ha $\left.{ }^{-1}\right)$ constituted 12.90 and $7.36 \%$ of total input energy in furrow and drip systems, respectively (Tables 1 and 2). In this study, average strawberry yield in the furrow and drip systems was 20,500 and 27,571.42 kg.ha ${ }^{-1}$, while the calculated total output energy was 38,950.00 and 52,385.70 MJ.ha' ${ }^{-1}$, respectively (Table 5). These results showed that the chemical energy in the drip system was $540.00 \mathrm{MJ} \mathrm{ha}^{-1}$, and was higher than furrow system (444.00 MJ.ha ${ }^{-1}$ ) (Tables 3 and 4).

The energy use efficiency, specific energy, energy productivity, and net energy of strawberry production in Kurdistan province were calculated using Eqs. (2) - (5) and tabulated in Table 5. Energy use efficiency was calculated as 2.40 in furrow system and 3.17 in drip system. The value of this index in the Kurdistan region indicated that strawberry fields with the drip irrigation system are more efficient in

$6 \quad$ Walailak J Sci \& Tech 2020; 17(1) 
http://wjst.wu.ac.th

the use of energy. The energy efficiency of growing strawberries proved considerably higher in our experiment than that found by Banaeian et al. [5] because of the cost of fuel. The energy use efficiency gives an indication of how much energy was produced per unit of energy utilized. It varies greatly according to the species, the age of the crop and the agronomic inputs [25]. The rate of net energy in the

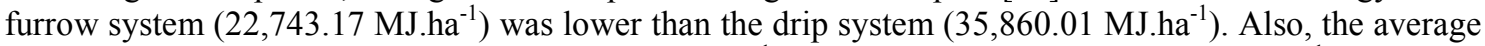
energy productivity of strawberry was as $1.26 \mathrm{~kg} \cdot \mathrm{MJ}^{-1}$ in the furrow system and $1.67 \mathrm{~kg} \cdot \mathrm{MJ}^{-1}$ in the drip system (Table 5). This means that 1.26 and 1.67 units of output were obtained per unit energy in the furrow and drip system, respectively. In general, optimum energy use in agriculture is reflected in 2 ways, i.e. an increase in productivity with existing level of inputs or conserving energy without affecting the productivity [20].

In this research, the specific energy was $0.79 \mathrm{MJ} . \mathrm{kg}^{-1}$ in the furrow system and $0.60 \mathrm{MJ} \cdot \mathrm{kg}^{-1}$ in the drip system. This means that 0.79 and $0.60 \mathrm{MJ}$ were needed to obtain $1 \mathrm{~kg}$ of strawberries in the furrow and drip systems, respectively. Canakci et al. reported that the specific energy for field crops and vegetable production in Turkey, was 5.24 for wheat, 11.24 for cotton, 16.21 for sesame, 0.98 for melon, 0.97 for water-melon and 1.14 for tomato [26].

The total energy input consumed in both furrow and drip irrigation systems could be classified as direct energy (46.86 vs. $45.26 \%$ ), indirect energy (53.13 vs. $54.74 \%$ ), renewable energy (28.34 vs. 20.56 $\%)$ and non-renewable energy (71.66 vs. $79.44 \%$ ), respectively (Table 6). Results showed that strawberry growing consumed more indirect energy than direct energy and more non-renewable energy than renewable energy in both systems. The water for irrigation and diesel fuel consumed were the main reason for the difference between direct and indirect energy inputs in strawberry production. The high ratio of non-renewable energy in the total energy inputs causes negative effects on the sustainability of agricultural production. Therefore, it is important to better utilize the renewable energy sources for increasing energy efficiency, so renewable energy production stimulates the agricultural land rural economy, improves the environment and enhances national energy security [5]. Several researchers have shown that, for different crops in Iran, indirect and non-renewable energies are higher than that of direct and renewable energies, respectively [5,16-21]. Wider use of renewable energy sources, increase in energy supply and efficiency of use can make an important contribution to meet sustainable energy development targets [27]. Integrated arable farming systems have been introduced to lessen the environmental impact of cropping and to promote sustainable resource use while maintaining crop production and farm incomes. These systems use a holistic approach of the principles and procedures known to reduce agronomic inputs and to diversify crops [28]. In Iran, the impacts of direct, indirect and renewable and non-renewable energies on cucumber yield were estimated as $0.39,0.61,0.27$ and 0.37 , respectively [20].

Table 6 Some energy forms in strawberry production under furrow and drip irrigation systems, in Kurdistan province, Iran.

\begin{tabular}{lllll}
\hline \multirow{2}{*}{ Item } & \multicolumn{3}{c}{ Quantity (MJ.ha $\mathbf{~}^{-\mathbf{1}}$ ) } \\
\cline { 2 - 5 } & Furrow system & Percentage & Drip system & Percentage \\
\hline Direct energy & $7,596.54$ & 46.86 & $7,480.33$ & 45.26 \\
Indirect energy & $8,610.29$ & 53.13 & $9,045.36$ & 54.74 \\
Total & $16,206.83$ & 100 & $16,525.69$ & 100 \\
Renewable energy & $4,593.53$ & 28.34 & $3,397.85$ & 20.56 \\
Non-renewable energy & $11,613.30$ & 71.66 & $13,127.84$ & 79.44 \\
Total & $16,206.83$ & 100 & $16,525.69$ & 100 \\
\hline
\end{tabular}


http://wjst.wu.ac.th

Table 7 GHG emissions ( $\mathrm{kg} \mathrm{CO}$ equivalent $\mathrm{ha}^{-1}$ ) from strawberry production under 2 irrigation systems in Kurdistan province, Iran.

\begin{tabular}{lllll}
\hline Item & Furrow system & Percentage & Drip system & Percentage \\
\hline 1. Diesel fuel & 158.39 & 20.72 & 215.33 & 16.77 \\
2. Nitrogen $(\mathrm{N})$ & 395.57 & 51.76 & 333.26 & 25.95 \\
3. Phosphorous $\left(\mathrm{P}_{2} \mathrm{O}_{5}\right)$ & 28.32 & 3.71 & 28.12 & 2.19 \\
4. Potash $\left(\mathrm{K}_{2} \mathrm{O}\right)$ & 12.65 & 1.66 & 11.00 & 0.86 \\
5. Fungicide & 17.55 & 2.30 & 14.43 & 1.12 \\
6. Machinery & 151.72 & 19.85 & 682.05 & 53.11 \\
Total & 764.28 & 100 & $1,284.19$ & 100 \\
\hline
\end{tabular}

\section{GHG emissions}

Table 7 shows the amount and percentage of GHG emitted derived from production of strawberries. The total amount of GHG emissions were 764.28 and $1,284.19 \mathrm{~kg} \mathrm{CO}_{2}$ equivalent $\mathrm{ha}^{-1}$ in the furrow and drip systems, respectively. Cerutti et al. found that emission of $1 \mathrm{~kg} \mathrm{CO}_{2}$-equivalents in an apple orchard produced $6.1 \mathrm{~kg}$ of apples [29]. In the furrow system, nitrogen fertilizer and diesel fuel had the highest share in GHG emissions, with 51.76 and 20.72 percent of total, respectively, but in the drip system, machinery had the highest share in GHG emissions, with 53.11 percent of the total (Table 7). Reducing the energy derived from fossil fuels within agricultural systems has important implications for decreasing atmospheric emissions of greenhouse gases, thus assisting the arrest of global warming. The identification of crop production methods that maximise energy use efficiency and minimise greenhouse gas emissions is very important [6]. Kehagias et al. reported that organic farming can minimize greenhouse gas emissions in agricultural systems [30].

Among the different agricultural practices, soil tillage is one of the greatest fossil fuel energy consumers and contributes to about $30 \%$ of the total energy use in crop production and in turn increases GHG emissions [31,10]. Tillage strategies need further evaluation not only during seedbed preparation, but also within the framework of the entire cropping system's mechanical operations [28]. Niu et al. showed a positive relationship between energy consumption and $\mathrm{CO}_{2}$ emissions in 8 Asian economies [32]. About $25 \%$ of global GHG emissions result from land clearance, crop production and fertilization. In contrast, large amounts of carbon can be fixed in the soil-crop system through photosynthesis and might increase soil organic carbon (SOC) storage to offset parts of the above GHG emissions [33].

\section{Conclusions}

The value of energy use efficiency in the Kurdistan region indicates that strawberry fields under a drip irrigation system are more efficient in the use of energy. Energy inputs in strawberry production were higher in the drip system than the furrow system. The main difference in energy consumption between the furrow and drip systems comes mainly from machinery and diesel fuel. We conclude that the high ratio of non-renewable energy in the total used energy inputs causes negative effects on the sustainability in agroecosystems and energy use efficiency which was calculated to be 2.40 in the furrow system and 3.17 in the drip system. These results highlight that the energy use efficiency can be increased by raising the crop yield and/or by decreasing energy inputs. The total GHG emissions were 764.28 and $1,284.19 \mathrm{~kg}$ $\mathrm{CO}_{2}$ equivalent $\mathrm{ha}^{-1}$ in the furrow and drip systems, respectively. From the environmental viewpoint, reduction of energy needs by integrated farming is a highly promising climate change mitigation option. In fact, lower fossil fuel inputs for crop management can deliver substantial and long-term GHG emission reductions [28] The limited water resources and the widespread use of unscientific and traditional irrigation systems which result in up to 3 times higher water consumption than actually needed for production of crops, are the major constraints facing agriculture in Iran [12]. Finally, from the water and energy consumption viewpoint, the drip irrigation system is suitable for strawberry production in Iran. This method is more nature-friendly, but also more costly to apply in the studied region. 
http://wjst.wu.ac.th

\section{Acknowledgements}

We are grateful to Gorgan University of Agricultural Sciences and Natural Resources (GUASNR), Dr. E. Roohi and strawberry growers in Kurdistan province.

\section{References}

[1] JR Quilty, JM Kinley, VOP Buresh, RJ Buresha, TQ Correa and JM Sandroa. Energy efficiency of rice production in farmers' fields and intensively cropped research fields in the Philippines. Field Crops Res. 2014; 168, 8-18.

[2] I Yilmaz, H Akcaoz and B Ozkan. An analysis of energy use and input costs for cotton production in Turkey. Renew Energ. 2005; 30, 145-55.

[3] T Nemecek, D Dubois, O Huguenin-Elie and G Gaillard. Life cycle assessment of Swiss farming systems: I. Integrated and organic farming. Agric. Syst. 2011; 104, 217-32.

[4] B Khoshnevisan, S Rafiee, M Omid, M Yousefi and M Movahedi. Modeling of energy consumption and GHG (greenhouse gas) emissions in wheat production in Esfahan province of Iran using artificial neural networks. Energy 2013; 52, 333-8.

[5] N Banaeian, M Omid and H Ahmadi. Energy and economic analysis of greenhouse strawberry production in Tehran province of Iran. Energ. Convers. Manag. 2011; 52, 1020-5.

[6] Intergovernmental Panel on Climate Change (IPCC). In: JT Houghton (ed.). Greenhouse Gas Inventory Reference Manual. IPCC Technical Support Unit, London, 1997.

[7] J Tzilivakis, DJ Warner, M May, KA Lewis and K Jaggard. An assessment of the energy inputs and greenhouse gas emissions in sugar beet (Beta vulgaris) production in the UK. Agric. Syst. 2005; 85, 101-19.

[8] S Singh, S Singh, CJS Pannu and J Singh. Optimization of energy input for raising cotton crop in Punjab. Energ. Convers. Manag. 2000; 41, 1851-61.

[9] E Saljnikov, A Saljnikov, S Rahimgalieva, D Cakmak, M Kresovic, V Mrvic and T Dzhalankuzov. Impact of energy saving cultivations on soil parameters in northern Kazakhstan. Energy 2014; 77, 35-41.

[10] G Pratibha, I Srinivas, KV Rao, BMK Raju, CR Thyagaraj, GR Korwar, B Venkateswarlu, AK Shanker, DK Choudhary, KS Rao and Ch Srinivasarao. Impact of conservation agriculture practices on energy use efficiency and global warming potential in rainfed pigeon pea-castor systems. Eur. $J$. Agron. 2015; 66, 30-40.

[11] M Royan, M Khojastehpour, B Emadi and H Ghasemi-Mobtaker. Investigation of energy inputs for peach production using sensitivity analysis in Iran. Energ. Convers. Manag. 2012; 64, 441-6.

[12] LT Ren, ZX Liu, TY Wei and GH Xie. Evaluation of energy input and output of sweet sorghum grown as a bioenergy crop on coastal saline-alkali land. Energy 2012; 46, 166-73.

[13] T Petr. Fisheries in Irrigation Systems of Arid Asia. FAO Fisheries Technical Paper. FAO, Rome, Italy, 2003, 1-150.

[14] Ministry of Jihad-e-Agriculture. Statistics Report of 2011-2012 Years. Statistics and Information Office of Jihad-e-Agriculture, Tehran, Iran, 2013.

[15] RC Fluck and CD Baird. Agricultural Energetic, In: Westport. AVI Publications, CT, 1982, 41-126.

[16] H Kazemi, M Shahbyki and S Baghbani. Energy analysis for faba bean production: A case study in Golestan province, Iran. Sustain. Prod. Consump. 2015; 3, 15-20.

[17] H Kazemi, B Kamkar, S Lakzaei, M Badsar and M Shahbyki. Energy flow analysis for rice production in different geographical regions of Iran. Energy 2015; 84, 390-6.

[18] MA Alikhani, HK Poshtmasari and F Habibzadeh. Energy use pattern in rice production: A case study from Mazandaran province, Iran. Energy Convers. Manag. 2013; 69, 157-63.

[19] A Tabatabaeefar, H Emamzadeh, MG Varnamkhasti, R Rahimizadeh and M Karimi. Comparison of energy of tillage systems in wheat production. Energy 2009; 34, 41-5.

[20] A Mohammadi and M Omid. Economical analysis and relation between energy inputs and yield of greenhouse cucumber production in Iran. Appl. Energ. 2010; 87, 191-6. 
http://wjst.wu.ac.th

[21] H Ghasemi-Mobtaker, A Akram and A Keyhani. Energy use and sensitivity analysis of energy inputs foe alfalfa production in Iran. Energ. Sust. Develop. 2012; 16, 84-9.

[22] M Torki-Harchegani, R Ebrahimi and M Mahmoodi-Eshkaftaki. Almond production in Iran: An analysis of energy use efficiency (2008-2011). Renew. Sustain. Energ. Rev. 2015; 41, 217-24.

[23] SK Lohan, MK Narang, GS Manes and N Grover. Farm power availability for sustainable agriculture development in Punjab state of India. Agric. EngInt: CIGR J. 2015; 17, 196-207.

[24] M Djevic and A Dimitrijevic. Energy consumption for different greenhouse constructions. Energy 2009; 34, 1325-31.

[25] MGM Mantineo, VD Copani, C Patane and SL Cosentino. Biomass yield and energy balance of three perennial crops for energy use in the semi-arid Mediterranean environment. Field Crops Res. 2009; 114, 204-13.

[26] M Canakci, M Topakci, I Akinci and A Ozmerzi. Energy use pattern of some field crops and vegetable production: Case study for Antalya region, Turkey. Energ. Convers. Manag. 2005; 46, 655-66.

[27] D Streimikiene, V Klevas and J Bubeliene. Use of EU structural funds for sustainable energy development in new EU member states. Renew. Sust. Energ. Rev. 2007; 11, 1167-87.

[28] F Alluvione, B Moretti, D Sacco and C Grignani. EUE (energy use efficiency) of cropping systems for a sustainable agriculture. Energy 2011; 36, 4468-81.

[29] AK Cerutti, S Bruun, D Donno, GL Beccaro and G Bounous. Environmental sustainability of traditional foods: The case of ancient apple cultivars in Northern Italy assessed by multifunctional LCA. J. Clean. Prod. 2013; 52, 245-52.

[30] MC Kehagias, MC Michos, GC Menexes, AP Mamolos, CA, Tsatsarelis, CD Anagnostopoulos and KL Kalburtji. Energy equilibrium and carbon dioxide, methane, and nitrous oxide-emissions in organic, integrated and conventional apple orchards related to Natura 2000 site. J. Clean. Prod. 2015; 91, 89-95.

[31] KP Singh, V Prakash, K Srinivas and AK Srivastva. Effect of tillage management on energy-use efficiency and economics of soybean (Glycine max) based cropping systems under the rainfed conditions in North-West Himalayan region. Soil Tillage Res. 2008; 100, 78-82.

[32] S Niu, Y Ding, Y Niu, Y Li and G Luo. Economic growth, energy conservation and emissions reduction: A comparative analysis based on panel data for Asian pacific countries. Energ. Policy 2011; 39, 2121-31.

[33] B Gao, X Ju, Q Meng, Z Cui, P Christie, X Chen and F Zhang. The impact of alternative cropping systems on global warming potential, grain yield and groundwater use. Agric. Ecosyst. Environ. $2015 ; \mathbf{2 0 3}, 46-54$

[34] B Ozkan, C Fert and CF Karadeniz. Energy and cost analysis for greenhouse and open field grape production. Energy 2007; 32, 1500-4.

[35] M Zahedi and HR Eshghizadeh. Energy use efficiency and economical analysis in cotton production system in an arid region: A case study for Isfahan province, Iran. Int. J Energ. Econ. Policy 2014; 4, 43-52.

[36] MGM Mantineo, VD Copani, C Patane and SL Cosentino. Biomass yield and energy balance of three perennial crops for energy use in the semi-arid Mediterranean environment. Field Crops Res. 2009; 114, 204-13. 